en criollo. Al piano, el maestro Murillo ha ido creciendo $y$ está en pleno derroche; vigor, sentimentalismo, infinito sentimiento. La orquesta ebria de ritmo toca marcando exacto, poderoso, el compás... El tiempo se ha ido tragando más horas, se empieza a hacer palpable la conveniencia de las despedidas.. Y todo ocurríó como si fuese un sueño. - J O S É V A S C O N C E L O S.

Exclusivo para Atenea en Chile.

\title{
DIVAGACIONES ALREDEDOR DE LA POESIA
}

\section{VI.-La poesía de hoy. Sus formas}

$15 \mathrm{~N}$ la poesía nueva se distinguen hasta ahora y principalmente, tres formas: el poema de pensamientos asociados, el poema deshumanizante y el poema que intenta, más que otra cosa, valorizarse por la música que resulta de la aproximación de las palabras que, a falta de relaciones lógicas, las tienen de color y de sonido. Esta última forma es la más noble y lá más difícil: es la poesía pura. Continúa en cierto modo y en su parte esencial, la tradición de la más alta poesía de todos los tiempos. Como formas inferiores o menores podríamos citar la de los caligramas y aquella tan socorrida por los poetas runrúnicos: la poesía a base de metáforas, especie de greguerías en verso. Por ejemplo:

la pluma corre sobre los renglones

como los trenes hacia la frontera

al salir del túnel el tren

desata un acordeón aportillado

alguien le dí cuerda el río

para que caminara más rápido

Pérez Santana y Reyes Messa: 12 poemas en un sobre.

Como ejemplo del poema de pensamiento asociados citaremos uno de Cendrars:

... Deshoja la rosa de los vientos

He aquí que zumban las tempestades desencadenadas

Los trenes ruedan en torbellino sobre sus redes 
embrolladas

Emboques diabólicos

Hay trenes que no sc encuentran jamás

Otros se pierden en el camino

Los jefes de estación juegan al ajedrez

Al chaquete

Al billar

Carambolas

Parábolas

La vía férrea es una nueva geometría

Siracusa

Arquímedes

Y los soldados que lo degollaron

$Y$ las galeras

Y los bajeles

Y las máquinas prodigiosas que él inventó

$\mathrm{Y}$ todas las matanzas

La historia antigua

La historia moderna

Los torbellinos

Los naufragios

Aún el del Titanic que leí en el diario

Tantas imágenes asociativas que yo no puedo desplegar en mis versos

Porque soy todavía un mal poeta

Porque el universo me desborda

Porque he descuidado asegurarme contra los accidentes ferroviarios

Porque no sé ir hasta el fin

$\mathrm{Y}$ tengo miedo.

¿Qué proceso psicológico ha generado este poema? Un proceso desarrollado fuera (o lejos) de la razón.

Puede dividirse el pensamiento-división bastante arbitraria por ciertoen dos capas: pensamiento-frase y pensamiento-asociación. Me explico. El pensamiento-frase es el pensamiento de las reflexiones voluntarias, el pensamiento racional, lógico, del que nos valemos, por ejemplo, para discutir el valor de una teoría científica, las probabilidades de éxito de un proyecto. Se le ha llamado forma del pensamiento superior; pero superior no significa nada. El pensamiento-asociación está a un nivel más profundo de la conciencia. Para trasladarlo hasta la palabra o la escritura requiérense esfuerzos considerables. Su carácter propio, en efecto, es de expresarse con dificultad; por lo común no consiste en frases sino en imágenes realmente visuales. A veces surgen palabras cuya significación puede ser reducida extrañamente a su sola sonoridad, a una inexplicable asociación de colores. Pensar en Rimbaud es todo uno con esto. Aquí nada tiene que hacer la lógica gramatical. El enlace de las ideas, si a esto puede llamarse ideas, se efectúa según asociaciones parciales y absolutamente ilógicas. La memoria es el único guía atento, ya al sonido y al color, ya a la anécdota del recuerdo. El verdadero fondo de todo pensamiento es el pensamiento-asociación. A éste se superpone el pensamiento-frase, que es una transformación incognoscible del pensamiento-asociación adaptable a la vida externa. Pero el verdadero 'yo" pensante piensa por asociaciones que, por lo demás, no siempre ni frecuentemente llegan a la conciencia. El pensamiento-asociación forma parte del sueño, del duerme-vela, del embotamiento cerebral, de esos 
estados en que se responde: «En nada», cuando algún inoportuno pregunta: ¿¿En qué piensa usted?? (J. Epstein: La poesía de hoy.)

Una asociación de imágenes, de recuerdos, de ideas sueltas forman el poema de Cendrars. En algunos versos se ve claramente el curso del pensamiento-asociación; en otros, el autor ha recurrido a la greguería en verso, que dijimos. No es un poema puro en su forma. Pero, en general, y apartándonos del modelo, podemos decir que esos poemas se hacen partiendo de una idea, de un sentimiento, de una emoción, de una imagen, de un recuerdo, fenómenos que despiertan en el cerebro del poeta otros, semejantes o distintos, que se van relacionando y seleccionando por el sonido, por el color, por la memoria, por el ritmo, y que, refiriéndose algunas veces al motivo de que partieron, no tienen entre sí orden lógico o de tiempo; es decir, cada uno de ellos, aunque provocado por la misma causa, posee un valor propio, una representación diversa de aquel motivo. En ocasiones, el circuito se interrumpe (tal vez por agotamiento del interés despertado por el agente provocador); pero como el cerebro jamás detiene su trabajo, surge inmediatamente otro germen y la cadena se reanuda. Entre un motivo y otro no hay a veces relación de ninguna especie. Otras las hay. Pero en general el poema presenta siempre fraccionamientos.

El lector dirá ahora: "Comprendo perfectamente la forma en que se hace un poema así; pero ¿en qué consiste su belleza?» La belleza de un poema así construído o generado resulta de varias causas, entre otras: de la frescura y gracia de las imágenes halladas, de los juegos de color y de sonido que haya entre sus palabras o frases, del contraste entre un recuerdo y otro. "Pero-volverá a decir el lector-estos son casi los mismos motivos que nos hacían sentir la belleza en un poema no nuevo.» $\mathrm{Y}$ el lector tendrá casi razón. La diferencia consiste en que la poesía no nueva se escribía en forma más o menos comprensible, se recurría-aunque esto pueda parecer paradojal-a las vías comprensibles para llegar a hacer sentir lo incomprensible, lo inefable. En esto se iba pareciendo a la prosa: tenía que explicar muchos para poder, al fin, significar algo. El poeta nuevo prescinde de las explicaciones, de los lentos procesos demostrativos, de las guías; ha rechazado todo aquello que era como un parche en el cuerpo de la poesía y no expresa sino lo esencial, es decir, el producto cerebral pristino, no mezclado ni con la razón ni con el sentimiento. Los pintores tienen una palabra muy feliz para significar esto. Llaman "redondeado» a un cuadro compuesto con elementos 
extraños al ofício mismo de la pintura, elementos intelectuales, elementos sentimentales, elementos literarios, etc., puestos en él para hacerlo más asequible al mal gusto del público y favorecer así su venta o su éxito. Quitándole a un cuadro "redondeado» todo aquello que lo «redondea», queda el esqueleto, lo esencial; esa es la pintura. Si no queda nada, es que no había nada.

El carácter general de la invención contemporánea está en la transposición de la emoción artística del plano sentimental al plano cerebral. (Canudo.)

En esta transposicion, en este brusco salto de lo sentimental a lo cerebral, el lector, con escaso o mal desarrollado sentido poético, no poeta o poeta ya mineralizado, se ha quedado atrás. Es falta de gimnasia.

Debo decir que el poema de Cendrars no me parece un excelente modelo. Es un poema combinado, donde se encuentran reunidas las dos formas primeras de que he hablado y donde la más importante, la tercera, falta. A mi juicio es un error presentar en un mismo poema varias formas poéticas o varias formas de versos. Esto desconcierta al lector e impide al poeta - a no ser que esto sea derivado de una incapacidad de perfección-crear una obra de arte lisa, de una pieza y con un solo material. El ideal debe ser esto último.

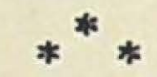

La segunda forma a que me he referido, el poema deshumanizante o descriptivo, es un poema cuya belleza resulta del placer intelectual que sus imágenes ilógicas provocan, de la sonrisa que excitan sus metáforas absurdas, de sus transposiciones y del descubrimiento o la creación de relaciones entre dos cosas que, lógicamente, no la tienen. Por ejemplo: cuando Pablo de Rokha dice:

\section{entusiasmo de tomates,}

no significa con ello, aparentemente, nada, puesto que no hay relación directa entre el entusiasmo y los tomates; pero la frase, a pesar de esto, despierta en el lector una sensación de forma y de color, casi una sensación visual. ¿Por qué? Porque si bien es cierto-como acabo de decir-que entre el entusiasmo y los tomates no hay relación directa, la hay, en cambio, indirecta. Veamos. Comúnmente, las palabras sugieren sensaciones de color, y no sólo las palabras, sino también las letras. Pues 
bien: la palabra entusiasmo evoca el color rojo o rosa subido. Si a esta palabra, que sugiere tal color, sigue la palabra tomates, que además de evocar el color que naturalmente posee, evoca también una imagen lineal, de forma, el resultado será que el lector verá mentalmente unos grandes tomates, rojos hasta la exageración, hasta el entusiasmo, podríamos decir. ¿Por qué son tan grandes y tan rojos? ¡Porque están entusiasmados! Esta combinación, ilógica, pero perfecta desde el punto de vista poético, provoca en el lector una carcajada o una sonrisa. Eso es suficiente. Los juegos cerebrales puros despiertan siempre alegría, y esta especie de alegría es también un producto de la sensación estética. No es necesario, por otra parte, que el lector haga las operaciones deductivas que yo he hecho. Si su cerebro ha salido del estado paleolítico medio de la humanidad, no necesitará hacer ninguna. La imagen y la sonrisa aparecerán inmediatamente después de leído el verso. Claro es que muchas personas, estéticamente, no quieren reír, quieren llorar; pero para esa gente hay literatura y literatos especiales. Que acudan a ella y a ellos.

Creo que con el verso que acabo de citar y analizar, el lector tendrá una impresión más o menos exacta de esta segunda forma poética. Citar más sería abusar de su paciencia. Con este pequeño ejemplo el lector podrá guiarse a través de los diferentes caracteres que presenta este modo poético actual. Digo diferentes caracteres porque, como el lector sospechará, todos los versos hechos según ese modo no son idénticos. Hay otros que describen la naturaleza y las cosas en forma arbitraria, desfigurándola, deshumanizándola. Todo arte es antifotográfico y la poesía, como arte que es, debe serlo también, so pena de dejar de ser arte. Pero si bien en esta deshumanización la lógica y la razón salen perdiendo, la inteligencia, en cambio, gana, pues con ello entra a un terreno desconocido, donde las sensaciones, las emociones, las imágenes, los ritmos, conservan su desnudez y su pureza primaria, relacionándose, no por lo que llegarán a significar exteriormente, sino por las afinidades que en su desnudez y pureza poseen. Como dice Epstein, 1. c.:

... podemos ver claramente la diferencia que separa a los autores modernos de Mallarmé: a éste jamás se le ocurrió la idea de que fuera posible prescindir de la inteligencia en provecho de esa misma inteligencia para suministrarle un alimento nuevo y realmente fresco.

Esta es la principal adquisición de la nueva poesía.-M AN U E L R O J A S. 